\title{
3D data related to the publication: A new, exceptionally preserved juvenile specimen of Eusaurosphargis dalsassoi (Diapsida) and implications for Mesozoic marine diapsid phylogeny
}

\author{
Scheyer Torsten M. ${ }^{1 *}$, Neenan James, M. ${ }^{2}$, Bodogan Timea ${ }^{1}$, Furrer Heinz ${ }^{1}$, Obrist Christian ${ }^{3}$, Plamondon \\ Mathieu $^{4}$ \\ ${ }^{1}$ University of Zurich, Palaeontological Institute and Museum, Karl Schmid-Strasse 4, CH- 8006 Zurich, Switzerland \\ ${ }^{2}$ Oxford University Museum of Natural History, Parks Road, Oxford, OX13PW, UK \\ ${ }^{3}$ Erliackerweg 8, 4462 Rickenbach, BL, Switzerland \\ ${ }^{4}$ Empa, Swiss Federal Laboratories for Materials Science and Technology, Center for X-ray Analytics, Überlandstrasse 129, CH-8600 Dübendorf, \\ Switzerland \\ ${ }^{*}$ Corresponding author: tscheyer@pim.uzh.ch
}

\section{Abstract}

The present contribution contains the 3D model and $\mu \mathrm{CT}$ dataset analyzed in the following publication: Scheyer, T. M., J. M. Neenan, T. Bodogan, H. Furrer, C. Obrist, and M. Plamondon. 2017. A new, exceptionally preserved juvenile specimen of Eusaurosphargis dalsassoi (Diapsida) and implications for Mesozoic marine diapsid phylogeny. Scientific Reports, https://doi.org/10.1038/s41598-017-04514-x.

Keywords: Ladinian, osteology, marine reptiles, postcranium, Prosanto Formation, Switzerland

Submitted:2017-05-02, published online:2017-06-30. https://doi.org/10.18563/m3.3.3.e2

\section{Model IDs \\ M3\#179_PIMUZA/III4380 \\ M3\#180_PIMUZA/IIII4380

\author{
Description \\ 94 extracted surfaces of \\ skeletal elements \\ Accompanying $\mu \mathrm{CT}$ dataset \\ (res. $84 \mu \mathrm{m})$
}

Table 1. 3D data of Eusaurosphargis dalsassoi

\section{INTRODUCTION}

Micro CT scan data were used to reconstruct the anatomy of a new, well preserved and almost completely articulated juvenile specimen of Eusaurosphargis dalsassoi Nosotti and Rieppel, 2003 (see Table 1 and Fig. 1) from the Prosanto Formation (early Ladinian, Middle Triassic), cropping out close to Ducanfurgga near Davos, Eastern Swiss Alps. The taxon was previously known only from the holotype, a disarticulated skeleton of a larger individual, found in the Besano Formation (Anisian-Ladinian boundary, Middle Triassic) of Besano, Lombardy, Italy (Nosotti and Rieppel, 2003) and from some further isolated and disarticulated remains found in the Vossenveld Formation (early Anisian), Winterswijk, The Netherlands (e.g., Klein and Sichelschmidt, 2014; Sander et al., 2014).

\section{METHODS}

The 3D surfaces were extracted by manually labeling the bones within VG Studio Max 2.1. The 3D surface models are provided in .ply format that can be opened with a wide range of freeware viewers. In addition the 3D dataset that was used for the 3D modeling is provided as well. These 3D data are provided under a CC-BY-NC licence, and as such, are only to be used for non-commercial purposes and producing and selling copies of the specimen without prior contacting the respective museums and repositories is not allowed.

\section{ACKNOWLEDGEMENTS}

Grant sponsor: Stiftung Bündner Naturmuseum Chur, Switzerland; Max Kuhn (Uster, Switzerland); Swiss Federal Laboratories for Materials Science and Technology (Empa); Swiss National Science Foundation (grants 205321_162775 to T.M.S. and P2ZHP3_162102 to J.M.N.)

\section{BIBLIOGRAPHY}

Klein, N., and O. J. Sichelschmidt. 2014. Remarkable dorsal ribs with distinct uncinate processes from the early Anisian of the Germanic Basin (Winterswijk, The Netherlands). Neues Jahrbuch für Geologie und Paläontologie, Abhandlungen 271, 307-314. https://doi.org/10.1127/0077-7749/2014/0391

Nosotti, S., and O. Rieppel. 2003. Eusaurosphargis dalsassoi n. gen. n. sp., a new, unusual diapsid reptile from the Middle Triassic of Besano (Lombardy, N Italy). Memorie della Società Italiana di Scienze Naturali e del Museo Civico di Storia Naturale di Milano 31, 3-33. 


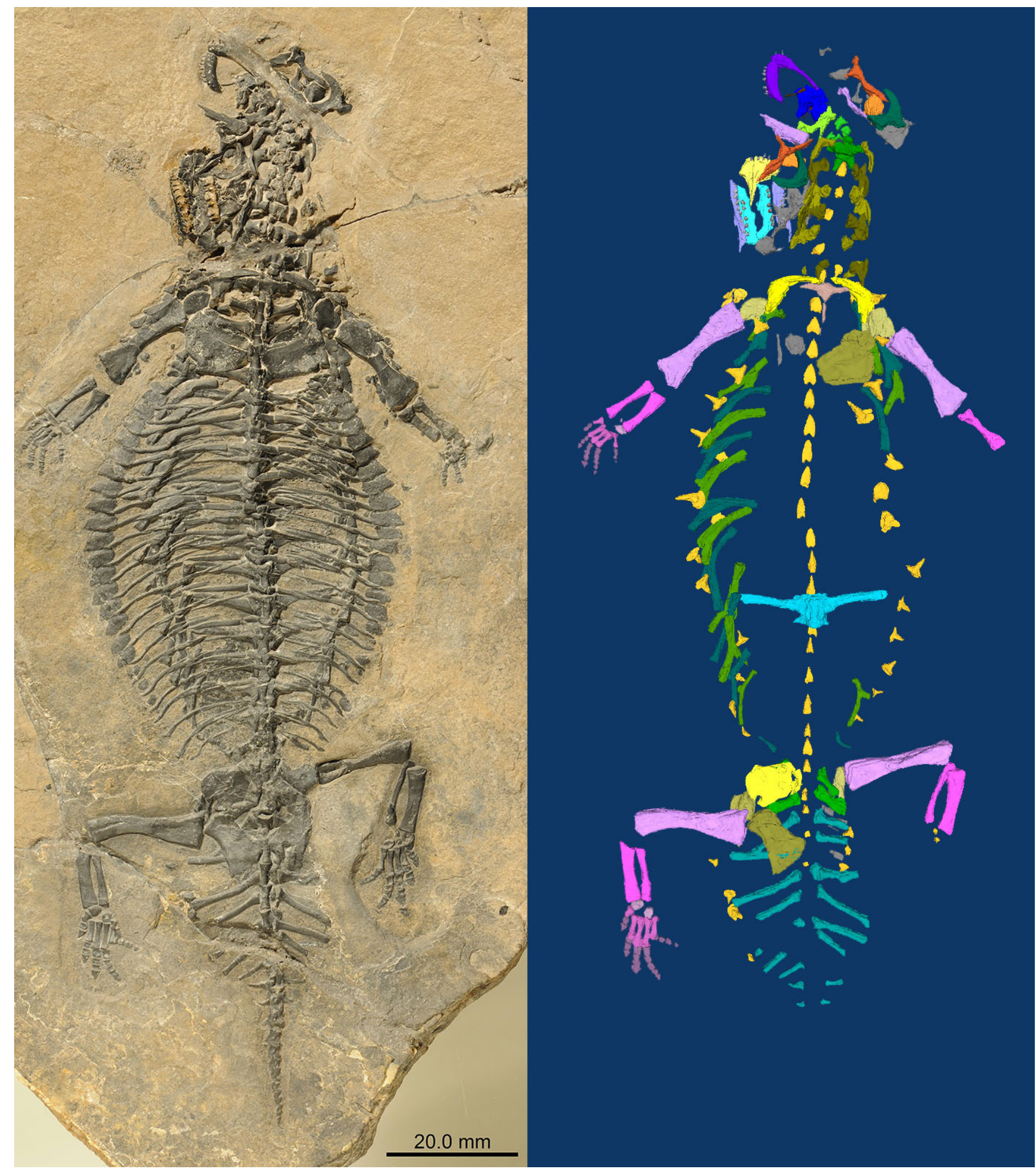

Figure 1. Physical specimen (left) and 3D model (right) of Eusaurosphargis dalsassoi (PIMUZ A/III 4380; Palaeontological Institute and Museum of the University of Zurich). This virtual model is accompanied by the 3D $\mu$ CT dataset. Colours were chosen to represent those used in the Supplementary Information file accompanying the original description of the specimen (see Abstract above). 
Sander, P. M., N. Klein, P. C. H. Albers, C. Bickelmann, and H. Winkelhorst. 2014. Postcranial morphology of a basal Pistosauroidea (Sauropterygia) from the Lower Muschelkalk of Winterswijk, The Netherlands. Paläontologische Zeitschrift 88, 55-71. https://doi.org/10.1007/s12542-013-0181-5.

Scheyer, T. M., J. M. Neenan, T. Bodogan, H. Furrer, C. Obrist, and M. Plamondon. 2017. A new, exceptionally preserved juvenile specimen of Eusaurosphargis dalsassoi (Diapsida) and implications for Mesozoic marine diapsid phylogeny. Scientific Reports, https://doi.org/10.1038/s41598-017-0451 4-x. 